\title{
Detecting Springs in the Coastal Area of the Gunungsewu Karst Terrain, Yogyakarta Special Province, Indonesia, Analysis using Fractal Geometry
}

\author{
Sari Bahagiarti Kusumayudha ${ }^{1}$
}

\begin{abstract}
The Gunungsewu area is a karst terrain with water scarcity, located in the Yogyakarta Special Province, adjacent to the open sea of Indian Ocean in the South. Shorelines of the Gunungsewu southern parts show fractal geometry phenomenon, and there can be found some groundwater outlets discharging to the Indian Ocean. One of the coastal outlets exists at the Baron Beach.The amount of water discharge from this spring reaches $20,000 \mathrm{l} / \mathrm{sec}$ in wet season, and approximately 9000 in dry season. In order to find other potential coastal springs, shoreline of the south coast is divided into some segments. By applying fractal analysis utilizing air photo of $1: 30,000$ scale, the fractal dimension of every shore line segment is determined, and then the fractal dimension value is correlated to the existence of spring in the segment being analyzed. The results inform us that shoreline segments having fractal dimension (D) $>1.300$ are potential for the occurrence of coastal springs.
\end{abstract}

Keywords-Karst terrain, water scarcity, fractal geometry, coastal spring.

\section{INTRODUCTION}

$\mathrm{G}$ unungsewu area of the Southern Mountains is situated in the Yogyakarta Special Province, Indonesia (Fig. 1). Morphologically it shows a conekarst-hills, comprises of limestone. Although the average annual precipitation in the area is about $2500 \mathrm{~mm}$, it is always subjected to dryness, because the rainwater rather infiltrate underground than flows on the land surface, due to high permeability and porosity of the rock formation. There are more than 250,000 people living in the Gunungsewu area, suffering from fresh water deficiency especially in dry season. In relation to that, some effort need to be done in order to help the local government find any new water sources. It is the reason of why this study was held.

The objectives of this study were to identify the existence of springs on the coastal line of the Gunungsewu karst area, and to find the quantitative correlation of the shoreline geometry and the existence of the springs. Approaches used in this study were fractal geometry analysis. In fractal analysis, the main thing to be done is determining the dimension of the object being analysis. In this study box counting method was utilized to derive the fractal dimension.

Such a shoreline displays fractal phenomenon (Fig. 2). In the south coast of Yogyakarta Special Province territory, there can be found some groundwater outlets.

${ }^{1}$ Sari Bahagiarti Kusumayudha is with Department of Geology, Faculty of Mineral Technology, Universitas Pembangunan Nasional "Veteran", Yogyakarta, 55283, Indonesia. E-mail: saribk@plasa.com.
Plenty of fresh water discharges to the open sea without any barrier. Some of the outlets are that performs at the Baron Beach, and Ngrenean Beach. By utilizing air photograph of $1: 30,000$ scale, the curve of the shorelines were traced and their fractal dimension were determined (Fig. 3).

\section{METHOD OF STUDY AND FRACTAL GEOMETRY}

In order to identify the existence of spring in the study area, this study utilizing air photo of $1: 30,000$ scale. The shoreline of the study area was traced and reprinted, and then divided into segments of about $2 \mathrm{~km}$ of length side. The fractal dimension of the curve of each shoreline segment was then determined by fractal analysis.

Mandelbrot (1983) used the word "fractal" to describe objects that are scale invariant, and are formed from a simple shape which grows more complex as the shape is repeated in miniature around the edges of the first shape (Xie 1993). Smaller versions of the shape grow out these smaller shapes, and so on to infinitive scale. The end result is infinite, swirling, and complex.

The natures of fractal are self-similarity, self-affinity, self-inverse, and self-squaring (Peitgen, et. al., 1992). Fractal scaling system is specified by a non-integer number called fractal dimension (Mandelbrot 1983), which can be used to quantify the degree of fractal irregularity (Sukmono, 1996). Fig. 4 shows a model of fractal geometry which is classified into self similar fractal.

There are several methods to determine a fractal dimension, e.g. similarity method, cantor dust method, balls covering method, sandbox method, and box counting method (Mandelbrot, 1983). The method used in this study is box-counting, because it is simple and more objective than other methods (Bunde \& Havlin, 1994).

\section{BOX DIMENSION}

The Fractal dimension derived from box counting method is called box dimension. Box counting method can be applied to objects which by Sahimi \& Yortsos (1990) are classified into statistical self-similar or statistical self-affine fractal, such as fractional Brownian motion (fBm) and fractional Gaussian noise (fGn). The determination of the fractal dimension is very easy, e.g. by drawing grids with certain lengthside $(r)$ over the fractal object. Then the fractal dimension $(D)$ is determined using equation (Tricot, 1996):

$D=\lim _{r \rightarrow 0} \frac{\log N r(F)}{-\log r}$ 
where $\operatorname{Nr}(F)$ is the number of boxes that cover the fractal set $(F)$, and $r$ is the length of the box side (Fig. 5).

The computation of $\operatorname{Nr}(F)$ is repeated by changing the length of the box side $(r)$, so that $r$ approaches zero. $N r(F)$ values and $r$ are plotted on a log-log graph to derive the fractal dimension, e.g., the slope of the plot (Tricot 1996).

When $\mathrm{F}$ is a curve shaped fractal object, and Pn is the length of the " $n$ " polygonal sequence of $F$, the length of the fractal object L(F) will be (Tricot, 1996):

$$
L(F)=\lim _{n \rightarrow \infty} L\left(P_{n}\right)
$$

When it is computed by box counting method, with the length of box side $=r$, and $\operatorname{Nr}(F)$ is the sum of boxes covering $\mathrm{F}$, the length of the fractal curve will be (Tricot, 1996):

$$
L(F)=\lim _{r \rightarrow 0} N r(F)
$$

\section{GEOLOGY AND HYDROGEOLOGY OF THE GUNUNGSEWU AREA}

The Gunungsewu Area morphometrically can be classified into a cone karst hills, and the karstification stage is categorized as mature stadium. Based on Physiographic classification (Van Bemmelen, 1949), this hillic area belongs to the Southern Mountains of Central Java which consist of three subzones, i.e., the Baturagung Range, the Panggung Massive, and the Plopoh Range in the north; the Wonosari Plateau in the central area; and the Gunungsewu subzone in the south.

A group of volcanic deposits, which consist of tuffaceous sandstone, lava, and breccia of Oligocene to early Miocene called the Besole Group, occupy the bottom part of the Gunungsewu stratigraphy. This basement at the northwestern part of the study area is overlain by marl of the Sambipitu Formation, while at the northeastern part is overlain by tuffaceous-marly limestone of the Oyo Formation. On the upper part of these rocks, there is the Gunungsewu limestones of middle to late Miocene age (Suyoto 1994). The Gunungsewu limestone is also called Wonosari Formation. It is overlain by marl of the Kepek Formation, alluvial, and Holocene volcanic deposits of Mount Merapi (Kusumayudha et al., 2000).

There are two different lithofacieses constituting the Gunungsewu limestones, i.e. bioclastic and reefs. In the field, the limestones perform two general factual characteristics; these are either karstic when the limestones are physically massive and hard, or chalky/calichic when the limestones are brittle and soft. In general, the limestones stratification gently inclines southward. The region is also dissected by faults that strike northwest-southeast and northeast-southwest. A syncline exists in the center part with a northeast trend axis, as can be indicated in the geological map of the study area (Fig. 6).

According to Kusumayudha et al. (1997, 1998, 2000), limestones in the Gunungsewu area develop two types of aquifers, karstic and non-karstic. The karstic aquifer with conduit flow is composed of karstified limestones, whereas the non-karstic aquifer with diffuse flow is composed of calichified limestones (caliche). Configuration of the basement of the Gunungsewu area performs subsurface highs and lows, ridge and basin.
This performance creates groundwater devides. Based on this hydrodynamic devides, the hydrogeologic system of the Gunungsewu area can be divided into 3 (three subsystems), they are Panggang subsystem, WonosariBaron subsystem, and Sadeng subsystem (Kusumayudha, 2002). The hydrogeologic map of the Gunungsewu area is shown in Fig. 7.

In the northern part of the Gunungsewu area, where bioclastic limestones occur, the water table is $5-10 \mathrm{~m}$ deep. This depth of water table increases abruptly to 150 $\mathrm{m}$ or more in the south, where it is underlain by reef limestones. The presence of caliche commonly results in the occurrence of perched aquifer. Areas of shallow groundwater and areas of deep groundwater in the study area are in general separated by faults, which act as seals. Some other specific hydrogeologic condition of the Gunungsewu area is the existences of surface flows sink, subsurface drainage, and outlets in the coastal area to Indian Ocean. The largest outlet has rate ranges from 4000 - $21000 \mathrm{l} / \mathrm{sec}$. There is also a presumed groundwater discharge through undersea spring (Kusumayudha et al., 2000, 2008).

\section{RESULTS OF THE ANALYSIS}

Results and analysis of all shorelines segments being studied can be seen in the Table 1. It shows that some shoreline segments in the south part of the Gunungsewu area have various value of fractal dimensions. The fractal dimensions of the curve of the shorelines are determined by using box counting method. There is a significant different result between the fractal dimensions of the Sepanjang beach and Baron beach. Sepanjang beach fractal dimension is $1.239 \pm 0.01$, while the fractal dimension of Baron beach is $1.665 \pm 0.01$. Plots of the two box counting application on the beaches are shown in Fig. 8 and Fig. 9, while Shoreline segments with fractal dimension (D) higher than 1.30 is potential to the existence of coastal spring, whereas on the segments with fractal dimension less than that, spring is absent. Figures 10, 11, and 12 show beaches those the shorelines have been analyzed, they are Ngungap beach, Baron beach, and Sepanjang beach.

After being verified, it can be concluded that there is a positive correlation between fractal dimension (D) of the shoreline and the existence or the water flow rate of coastal springs. The higher the fractal dimension value of the shorelines, the larger the flow rate amount of the outlets.

\section{DISCUSSIONS}

Karst is a diagenetic facies, an overprint in sub-areally exposed carbonate bodies, produced and controlled by dissolution, erosion, and migration of carbonates by meteoric water (Esteban, 1979). The lithology composing karst system is mainly limestones. As it is mentioned in the previous elaboration, the study area geologically consists of limestones of Wonosari Formation. Limestone is easy to be dissolved by acidic water. In the karst area, dissolution of limestone is much triggered by the presence of $\mathrm{CO}_{2}$ in the water, following the chemical reaction:

$\mathrm{H}_{2} \mathrm{O}+\mathrm{CO}_{2} \leftrightarrow 2 \mathrm{HCO}_{3}$ $\mathrm{CaCO}_{3}+\mathrm{HCO}_{3} \leftrightarrow \mathrm{Ca}\left(\mathrm{HCO}_{3}\right)+\mathrm{H}_{2} \mathrm{O}$ 
$\mathrm{CaHCO}_{3}+\mathrm{H}_{2} \mathrm{O} \leftrightarrow \mathrm{Ca}^{2+}+\left(\mathrm{HCO}_{3}\right)^{-}+\mathrm{H}_{2} \mathrm{O} \leftrightarrow \mathrm{Ca}^{2+}+$
$\left(\mathrm{HCO}_{3}\right)^{-}+\mathrm{CO}_{3}^{2-}+\mathrm{H}_{2} \mathrm{O}$

Groundwater flow in the karst terrain is not controlled by Darcy's law, due to its conduit flow type, while Darcy works with diffuse flow. When water flows in such a conduit or channel, it tends to move with high velocity and turbulent. In this case, erosion of limestone by the moving water will be more intensively to occur than that of dissolution process. After the erosion process, limestone particle transported by the moving water will be dissolved.

The existence of springs at the coast with fractal dimension higher than 1.300 , in the study area is interesting to be discussed. As a fractal object, shoreline geometry belongs to two-dimensional self affine fractal (Kusumayudha, 2005). This kind of fractal can be classified into statistical fractal, and therefore to determine the dimension, box counting method is appropriate. As a curve geometry, shoreline segment with fractal dimension higher than 1.300 displays more complex curvature. In fractal, it is usually identified that the higher in dimension value, the more complex the geometry of the object. Concerning the shoreline with complex geometry, in the field, it is representing irregular and steep cliff, as shown by Baron and Ngungap beaches (Fig. 10 and Fig.11). The geometry of these shorelines is interpreted originally formed by interaction of wave's abrasion and fresh water discharge erosion. The results are irregular cliff shape. On the other hand, the steep cliff is created by uplifting process and accelerated by abrasion.

When there is no existence of fresh water discharge through spring, erosion process of the limestone will be only come from the sea side, making the geometry of the shoreline relatively regular or straight (Fig. 12). On the other hand when the erosion process comes from both sea side and land side, there will be force from the sea, and some action from the land direction. This is why the geometry then becomes to be more complex.

The irregularity of the shoreline shape is also correlated to the amount of water discharge of the spring. As mentioned above, water moving in the channel system is rather eroding than dissolving. The higher the speed and the larger the amount of flowing water, the more intensive erosion process, and bring about the shape of the mouth of the spring more rough or uneven.

\section{CONCLUSION}

1. Fractal geometry analysis is able to be applied to quantify the shape of shoreline in the coastal part of the Gunungsewu karstic area, Indonesia. The fractal dimension of the shoreline in the study area ranges from $1.230 \pm 0.01$ to $1.665 \pm 0.01$.

2. On the shoreline segments with fractal dimension (D) higher than 1.300 spring is present, whereas on the segments with fractal dimension less than 1.300 spring is absent. Therefore it can be concluded that in the Gunungsewu Area, there is a correlation between the fractal dimension value of shoreline of a coast and the existence of spring.

3. At Ngobaran - Ngrenean shoreline with fractal dimension $(D)=1.382 \pm 0.01$, there is spring with
$2001 / \mathrm{sec}$ flow rate; at western of Teluk Baron, $\mathrm{D}=$ $1.469+0.01$, there is spring with $300 \mathrm{l} / \mathrm{sec}$ flowrate; at Slili, $\mathrm{D}=1.324 \pm 0.01$, there is spring with 50 $2001 / \mathrm{sec}$ flow rate; at Sundak, D = $1.317 \pm 0.01$, there is spring with 50-200 1/sec flow rate; at Baron beach, $\mathrm{D}=1.665 \pm 0.01$, there is spring with 9000 1/sec flow rate; and at Ngungap-Sadeng beach, $\mathrm{D}=$ $1.630 \pm 0.01$, there is spring with $>5000 \mathrm{l} / \mathrm{sec}$ flow rate. Therefore it can be stated that the fractal dimension of shoreline correlates to the flow rate of the existing spring. The higher the fractal dimension, the larger the amount of spring flow rate.

\section{REFERENCES}

[1] A. Bunde and S. Havlin, 1994, "Fractals in science", Springer Verlag, p 298.

[2] Esteban M. 1996. "Karst system from prospect to reservoir", Carbonates International Ltd.

[3] S. B. Kusumayudha, Zen M.T., Notosiswoyo S., and Gautama R.S., 1997, "Fractal analysis of river Oyo flow in the Southern Mountains Central Java, a Lithologic and Geologic Structure Control". Jurnal Teknologi Mineral Vol. IV. 2, pp 71-86.

[4] S. B. Kusumayudha, Zen M.T., Notosiswoyo S., and Gautama R.S., 1997, "Identification of fractal pattern on underground river and surface topography of Karstic limestones in the Southern Mountains, Central Java", Proceedings of the $22^{\text {nd }}$ Scientific Annual Meeting of HAGI, pp 176-179.

[5] S. B. Kusumayudha, Zen M.T., Notosiswoyo S., and Gautama R.S., 1998, "Study on carbonate rocks distribution based on their fractal characteristics, valley pattern, and secondary porosity", Jurnal Teknologi Mineral Vol. V.1, pp 21-28.

[6] S. B. Kusumayudha, Zen M.T., Notosiswoyo S., and Gautama R.S., 2000, "Fractal analysis of the Oyo river, Cave system, and topography of the Gunungsewu Karst area, Central Java, Indonesia”. Hydrogeology Journal, Vol. 8, pp 271 - 278.

[7] S. B. Kusumayudha, 2002, "Sistem hidrogeologi Gunungsewu", Prosiding Sumberdaya Geologi Daerah Istimewa Yogyakarta dan Jawa Tengah, Ikatan Ahli Geologi Indonesia (IAGI) Pengda DIY-Jateng, pp $130-141$

[8] S. B. Kusumayudha S.B, 2004, "The application of fractal geometry analysis to groundwater exploration", Research Basin and Hydrological Planning, A. A. Balkema.

[9] S. B. Kusumayudha, 2005, "The beauty of fracral in Farst system case study Gunungsewu area, Central Java, Indonesia". Proceedings of International Conference of Women Engineers and Scientists, Seoul.

[10] S. B. Kusumayudha, 2008, "The use of fractal geometry as an alternative method to groundwater resource exploration", Inaugural Speech, UPN Veteran Yogyakarta Press.

[11] Mandelbrot B.E, 1983, "The fractal of nature", Springer Verlag, p 468.

[12] Peitgen H.O., Jurgens H., and Saupe D. 1992. "Fractal for the classroom: part one introduction to frcatals and chaos, Springer Verlag, p 450.

[13] M. Sahimi, and Y.C. Yortsos, 1990, "Applications of fractal geometry to porous media : A review", SPE 20476 Paper.

[14] Sukmono S., 1996, "Fractal analysis on seismicity of the active fault of Sumatra", Proceedings of HAGI Annual Meeting XX.

[15] Suyoto, 1994. "Stratigraphic sequence of the Gunungsewu carbonates", Proceedings of IAGI Annual Meeting XXIII. Vol. 1, pp 19-32.

[16] Tricot C, 1996, "Curves and fractal dimension", Springer Verlag, pp. 323.

[17] Turcotte D.L., 1993, Fractals and chaos in Geology and Geophysics, Cambridge University Press, pp. 221.

[18] Van Bemmelen R.W., 1949, "The geology of Indonesia", IA, Martinus Nijhoff The Hague, pp. 792.

[19] Xie H, 1993, "Fractals and rock mechanics", A.A. Balkema, pp. 453. 


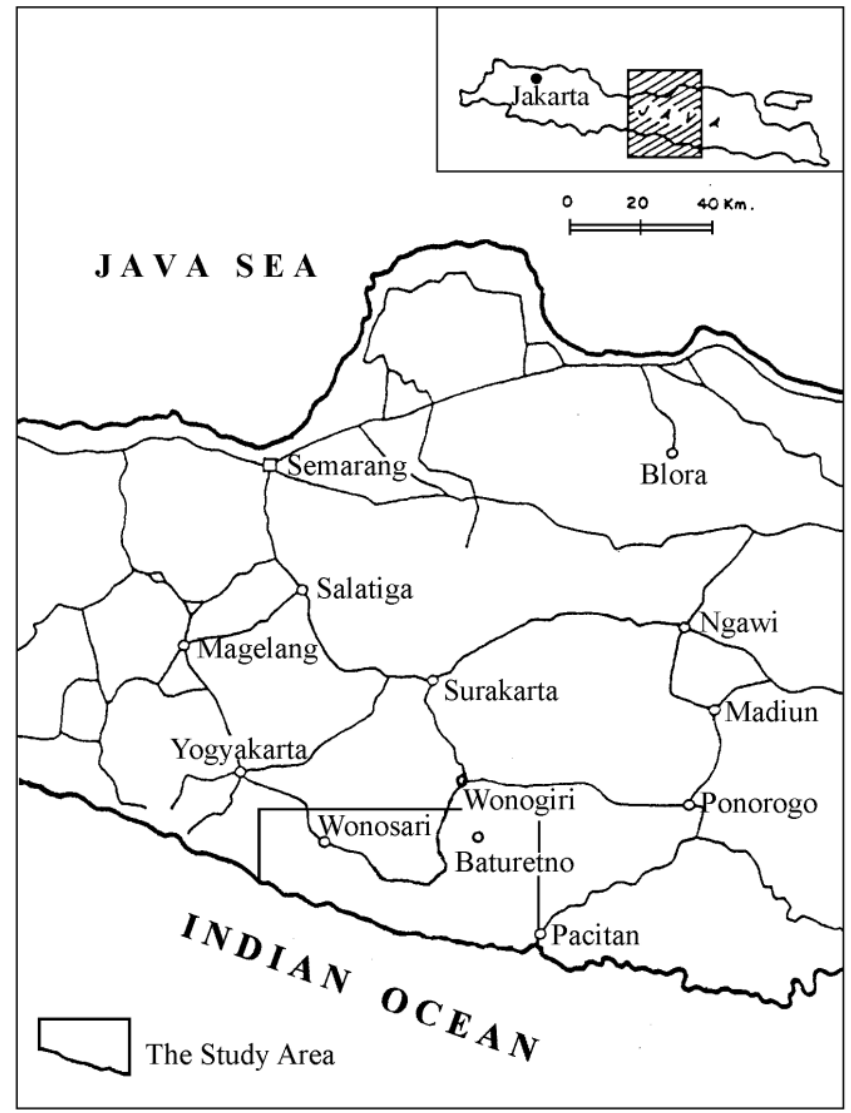

Fig. 1. Location map of the study area
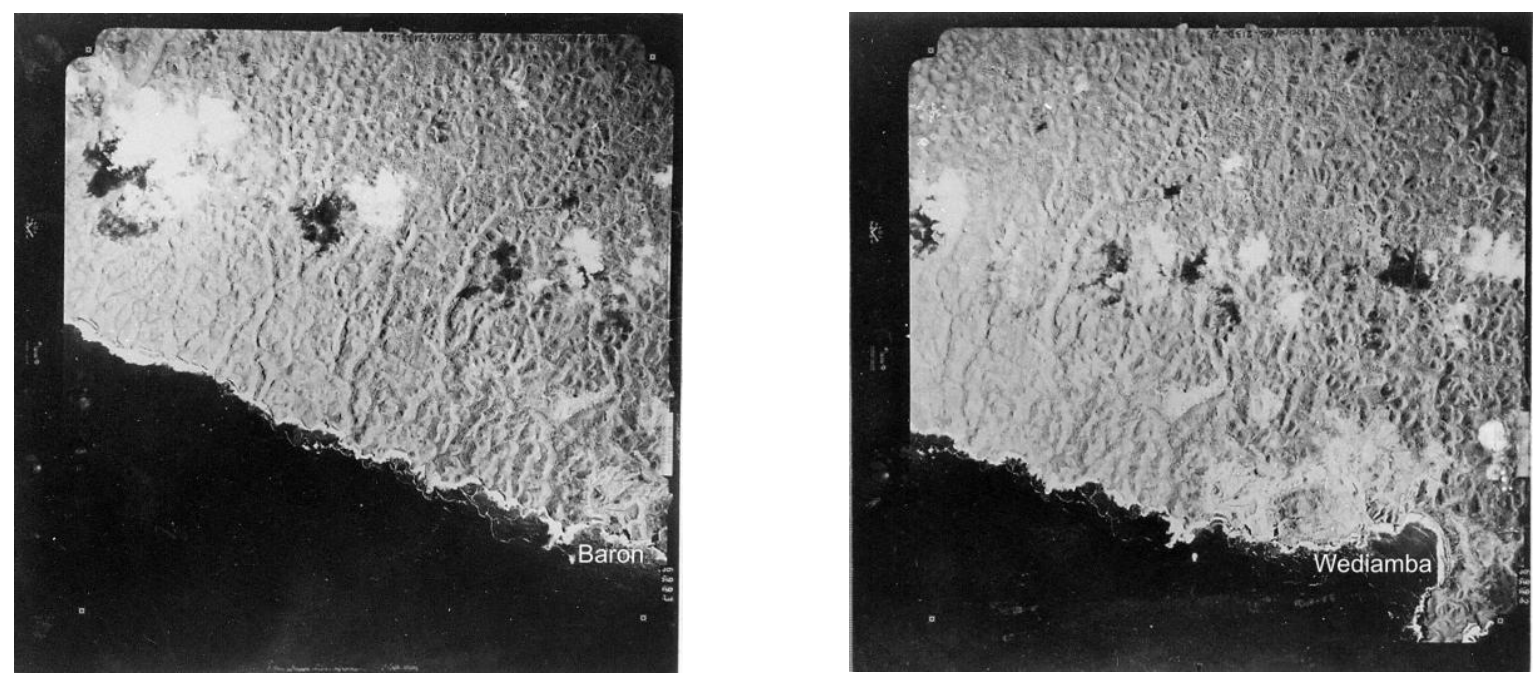

Fig. 2. Air photograph $1: 30,000$ scale, showing fractal shorelines of Baron beach (1) and western Wediamba beach (2) 


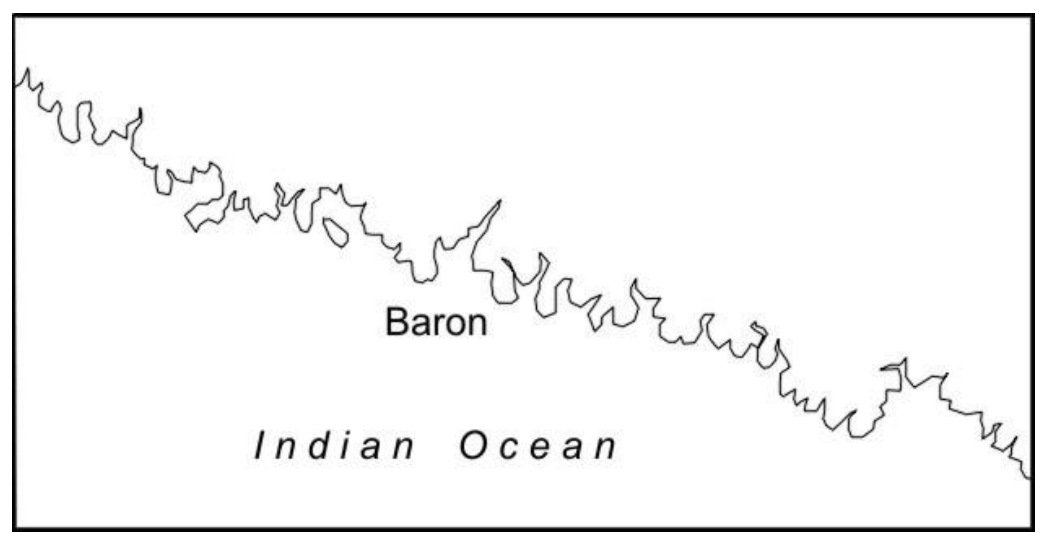

Fig. 3. Shoreline of Baron beach and the surrounding area that shows fractal geometry phenomenon

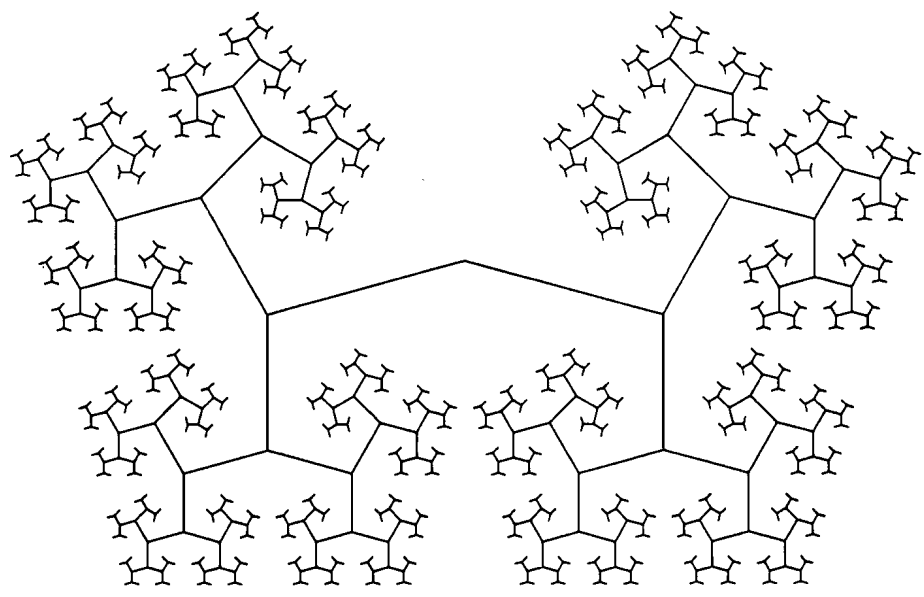

Fig. 4. A model of self similar fractal: Tree branches [11]

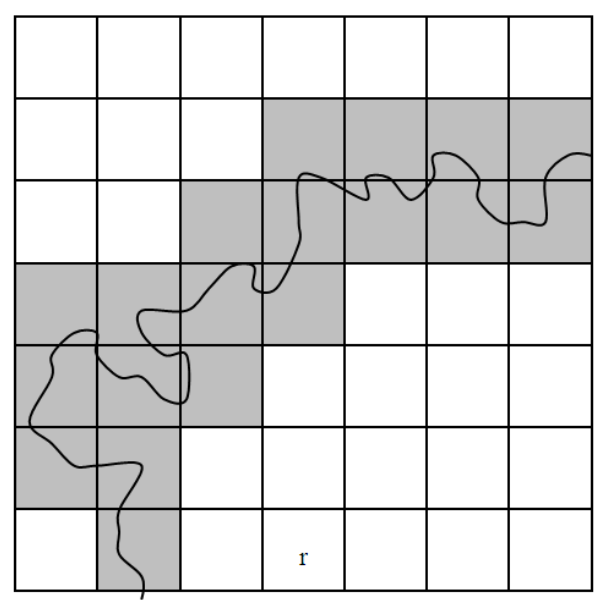

Fig. 5. A curve in box counting method, $\operatorname{Nr}(\mathrm{F})=19($ the number of boxes that cover the fractal set $(F))$, and $r=1 \mathrm{~cm}$ (the length of the box side) 


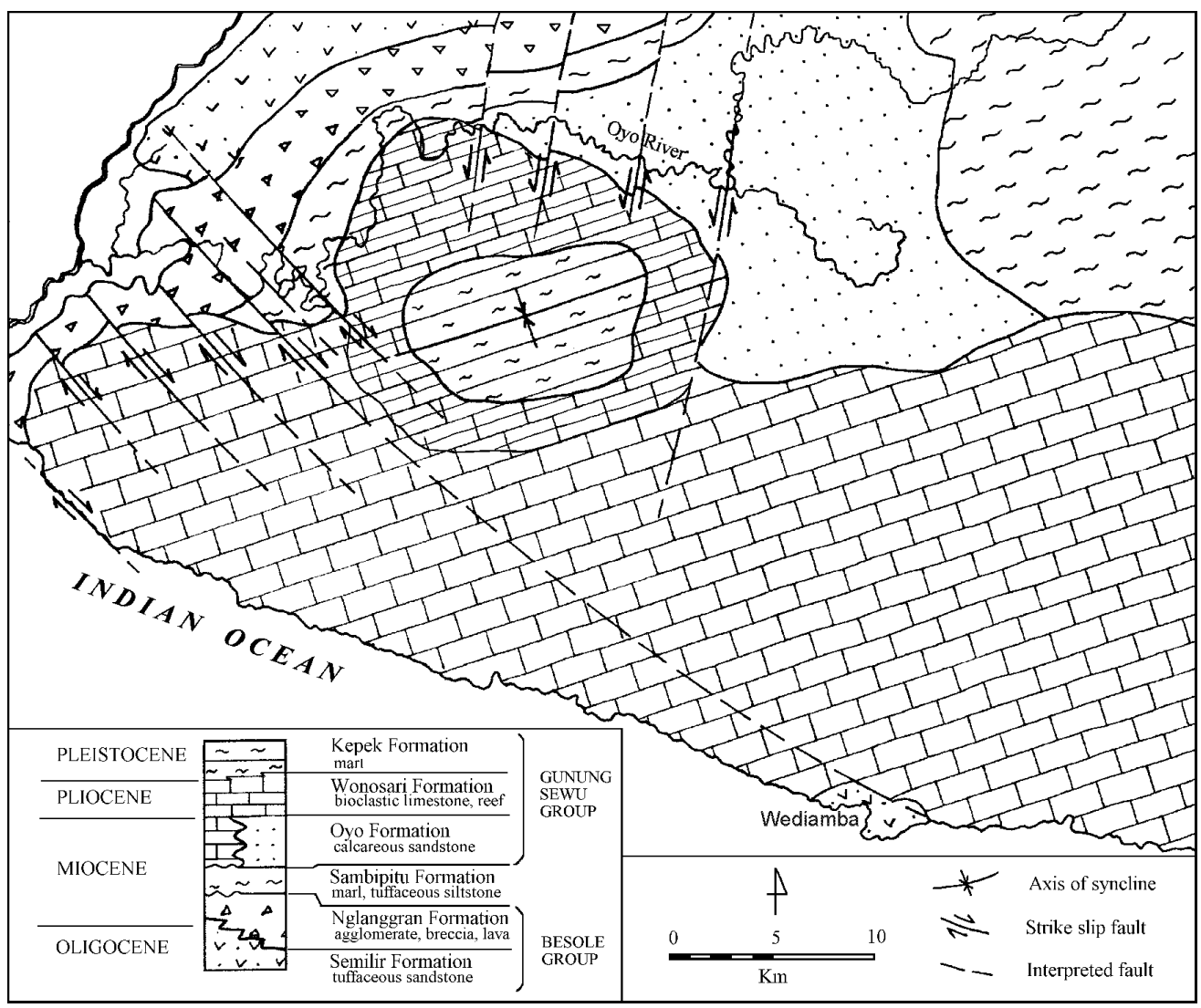

Fig. 6. Geologic map of the Gunungsewu area [7]

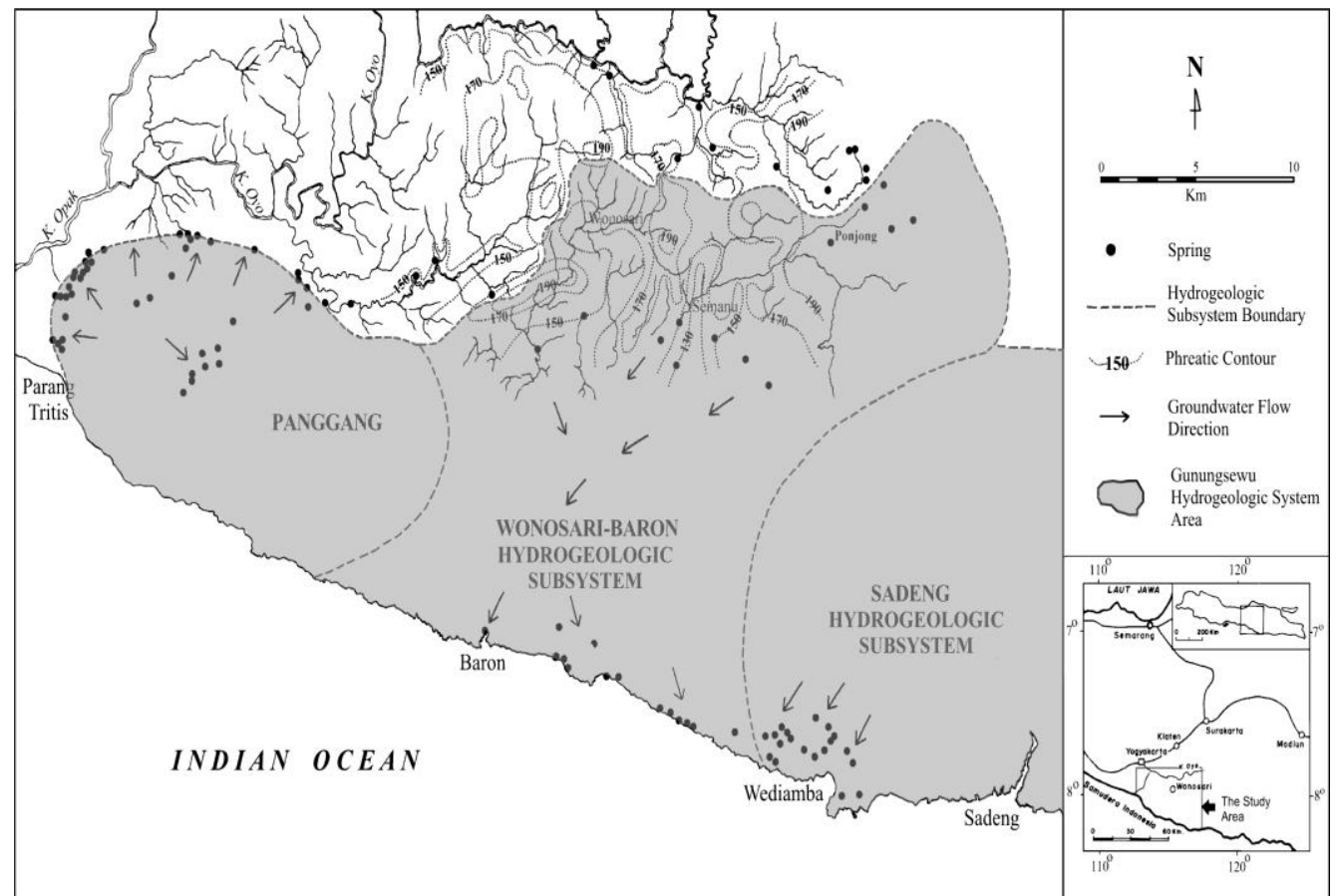

Fig. 7. Hydrogeologic map of the Gunungsewu Area [7] 


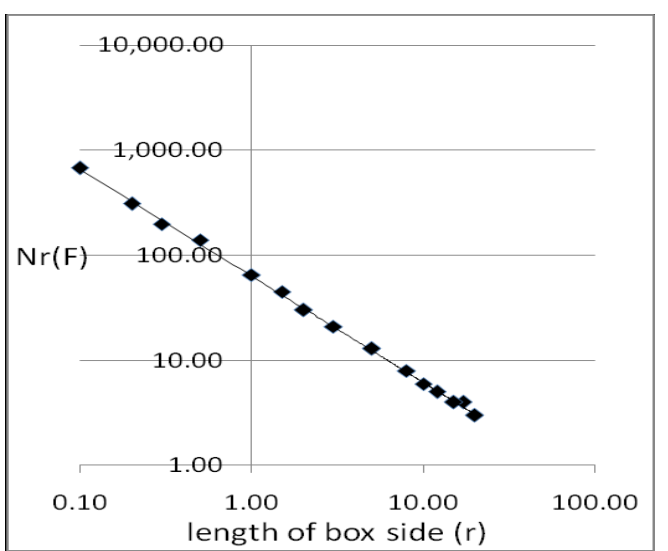

Fig. 8. Plots result of box counting method for Sepanjang shoreline

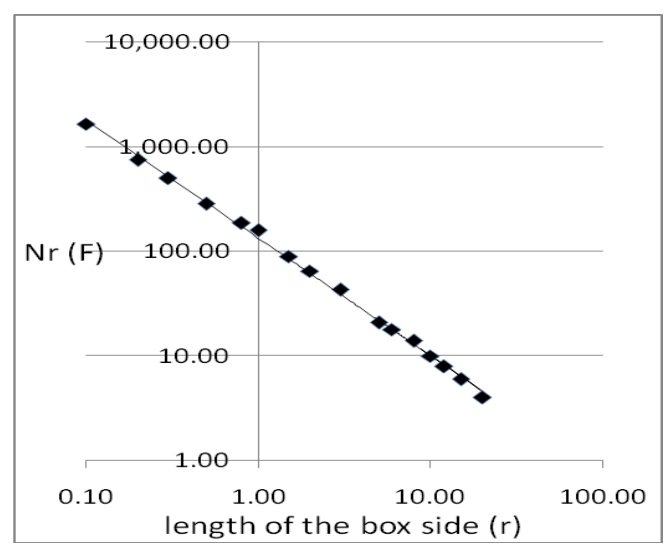

Fig. 9. Plots result of box counting method for Baron shoreline

TABLE 1.

Fractal Dimensions of the SHORElines AND the EXISTENCE of COASTAL SPRINGS

\begin{tabular}{|c|c|c|c|c|c|}
\hline Segment & Location & Frctal Dimension & Spring & Rate $(1 / \mathrm{sec})$ & Remarks \\
\hline 1 & Teluk Becici & $1.230 \pm 0.01$ & absent & & verified \\
\hline 2 & Teluk Pule - Gebangkara & $1.284 \pm 0.01$ & absent & & verified \\
\hline 3 & Teluk Nunggah - Karangtelu & $1.445 \pm 0.01$ & present & $?$ & presummed \\
\hline 4 & Teluk Nguluran - Langkap & $1.354 \pm 0.01$ & present & $?$ & presummed \\
\hline 5 & Ngobaran - Ngrenean & $1.382 \pm 0.01$ & present & 200 & verified \\
\hline 6 & Teluk Baron - western coast & $1.469 \pm 0.01$ & present & 300 & verified \\
\hline 7 & Kukup - Spanjang - Drini & $1.239 \pm 0.01$ & absent & & verified \\
\hline 8 & Watulawang & $1.315 \pm 0.01$ & present & $?$ & presummed \\
\hline 9 & Watulawang - Wediamba & $1.308 \pm 0.01$ & present & $?$ & presummed \\
\hline 10 & Wediamba - western coast & $1.365 \pm 0.01$ & present & $?$ & presummed \\
\hline 11 & Eastern coast of Wediamba & $1.355 \pm 0.01$ & present & $?$ & presummed \\
\hline 12 & Ngungap - Sadeng & $1.630 \pm 0.01$ & present & $>5000$ & verified \\
\hline 13 & $\begin{array}{l}\text { Eastern coast of Sadeng - } \\
\text { Tanjung Dadapan }\end{array}$ & $1.448 \pm 0.01$ & present & $?$ & presummed \\
\hline 14 & Slili & $1.324 \pm 0.01$ & present & $50-200$ & verified \\
\hline 15 & Sundak & $1.317 \pm 0.01$ & present & $50-200$ & verified \\
\hline 16 & Baron Beach & $1.665 \pm 0.01$ & present & 9000 & verified \\
\hline
\end{tabular}

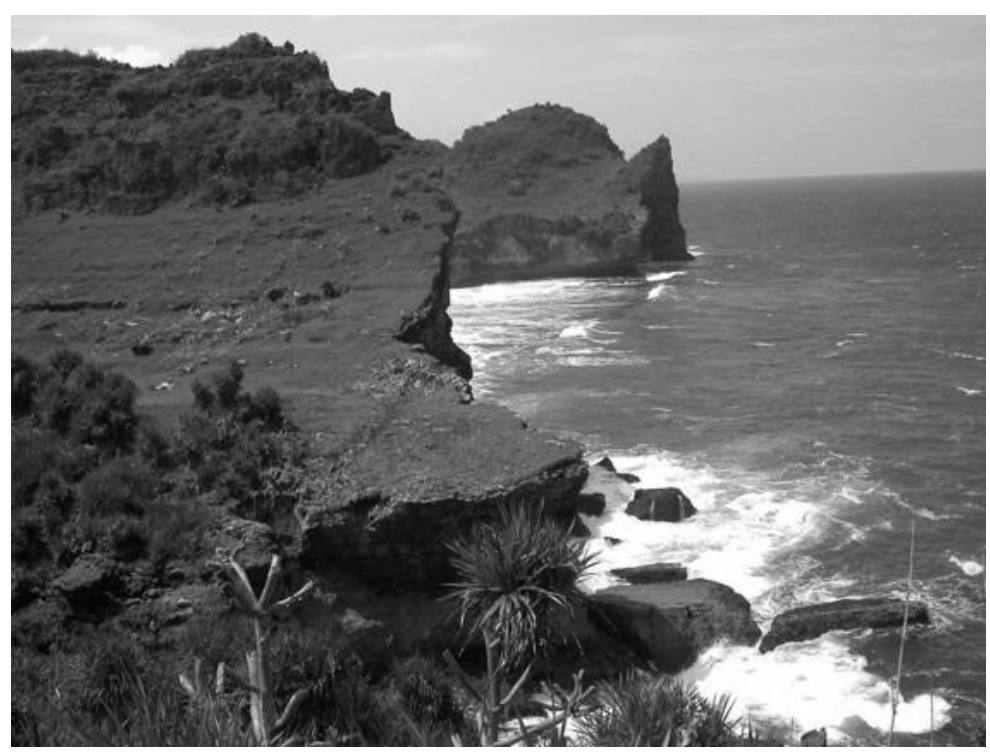

Fig. 10. Ngungap Beach, fractal dimension $1.630 \pm 0.01$, potential for the occurrence of coastal spring 


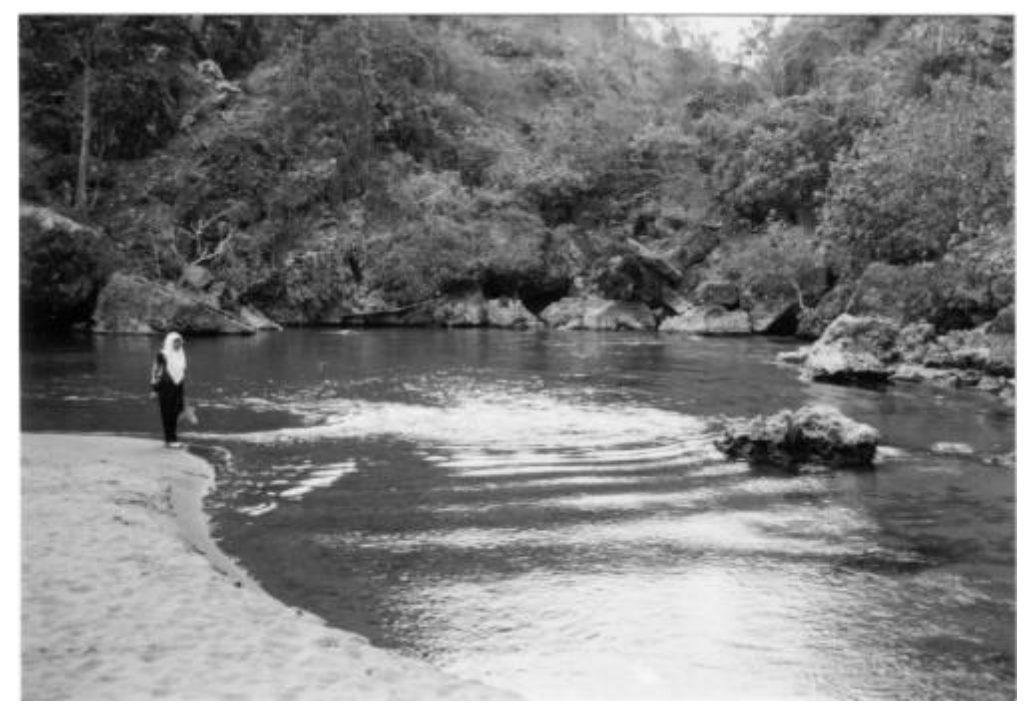

Fig. 11. Baron Beach, fractal dimension $1.665 \pm 0.01$, there is spring with $9000 \mathrm{l} / \mathrm{sec}$ rate in the dry season, and $22000 \mathrm{l} / \mathrm{sec}$ in the wet season

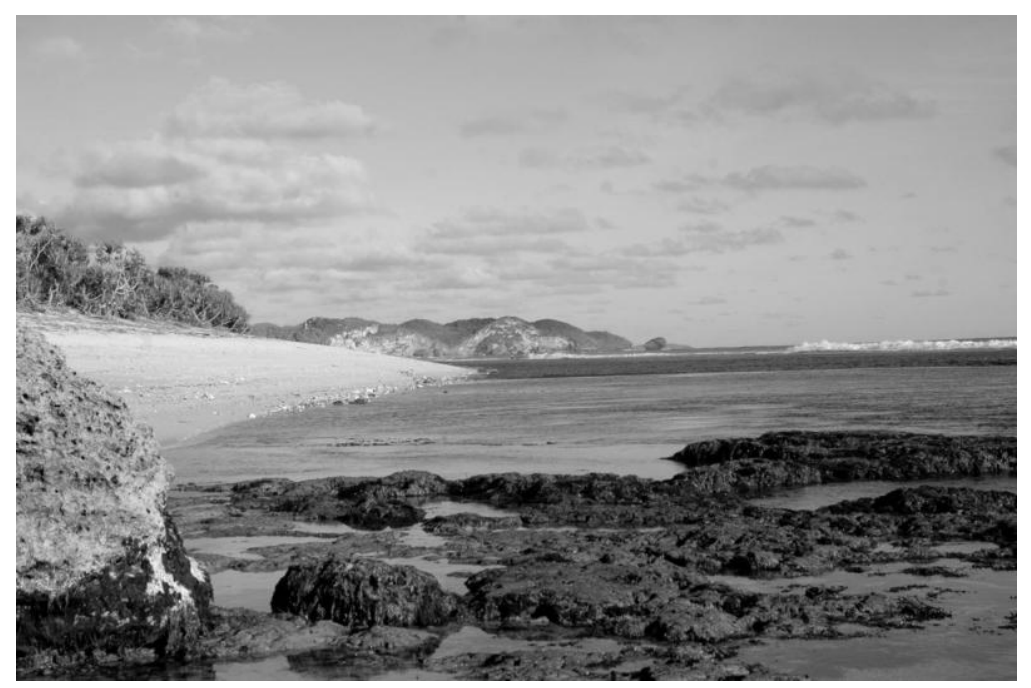

Fig. 12. Sepanjang Beach, fractal dimension $1.239 \pm 0.01$, no coastal spring 


\section{ACKNOWLEDGEMENT}

The editors would like to thanks to all the reviewers for their hard work in reviewing the papers.

1. Prof. Agoes Soegianto (Department of Biology, Universitas Airlangga (UNAIR)

2. Dr. Niken Satuti Handayani (Department of Biology, Universitas Gadjah Mada (UGM))

3. Prof. Paulus Indiyono (Department of Marine Engineering, Institut Teknologi Sepuluh Nopember (ITS))

4. Dr. Erwandi (Indonesian Hydrodynamic Laboratory)

5. Prof. Rohani J. Widodo (Department of Electrical Engineering, Institut Teknologi Sepuluh Bandung (ITB))

6. Dr. Pekik Argo Dahono (Department of Electrical Engineering, ITB)

7. Dr Muhammad Nurdin (Department of Electrical Engineering, ITB)

8. Lukito Edi Nugroho, Ph.D (Department of Electrical Engineering, UGM)

9. Dr. Suminar Pratapa (Department of Physics, ITS)

10. Dr. Nurul Taufiqu Rahman (The Indonesian Institute of Physics Sciences (LIPI))

11. Prof. Bambang Pramudono (Department of Chemical Engineering, Universitas Diponegoro (UNDIP))

12. Prof. Mohammad Nasikin (Department of Chemical Engineering, Universitas Indonesia (UI))

13. Dr. Wahyudi (Department of Marine Engineering, ITS)

14. Dr. M. Mustain (Department of Marine Engineering, ITS) 